\title{
CONCEPTUALISING THE CONSTRUCTIVE TRUST
}

\author{
Andrew D. Hicks, Law School, University of Hull *
}

\section{Introduction}

In an oft-quoted article, published in this journal in 1977, Ronald Maudsley wrote that the constructive trust "is an instrument created by the law to do justice" but that it also "needs to have some shape." Almost thirty years on and we are still trying to find that shape, or at least one that can do the job adequately. The conceptual choice is apparently two-fold: either "institutional" or "remedial". The institutional constructive trust is characterised as a rule-based property entitlement that arises at the time of the facts giving rise to the claimant's cause of action. The remedial constructive trust is characterised as a discretionary remedy that confers on the claimant a proprietary interest only when declared by a court of competent jurisdiction. ${ }^{2}$ The choice, however, is not simply one of alternatives. Judges and jurists have not been uniform in the content they have given either abstraction. These numerous differences, not always appreciated, have potentially far reaching implications.

How, then, are we to choose between these possibilities? The constructive trust does not exist in nature. It is not capable of being simply tracked down in its natural environment and scientifically dissected to expose its essential anatomy. Rather, it is a construct developed in legal discourse to serve both

* This article draws upon doctoral research undertaken at the University of Hull. I am grateful to Nick Parry for his supervision of that project. I would also like to extend special thanks to Craig Rotherham of Nottingham University for his extensive and helpful comments on earlier drafts of this paper. My thanks also to an anonymous referee who made a number of useful suggestions. Responsibility for the final product remains with me.

1 Maudsley, "Constructive Trusts" (1977) 28 NILQ 123 at p.137.

2 On the distinction see Westdeutsche Landesbank Girozentrale v Islington LBC [1996] AC 669 at 714-715 per Lord Browne-Wilkinson; Re Polly Peck International plc (in administration) (No.2) [1998] 3 All ER 812; Fortex Group Ltd v MacIntosh [1998] 3 NZLR 171 at 172-173, 175-177 per Tipping J; Commonwealth Reserves I v Chodar [2001] 2 NZLR 374 at [36]-[63] (Glazebrook J); Dickie v Torbay Pharmacy (1986) Ltd [1995] 3 NZLR 429 at 441 (Hammond J); Atlas Cabinet \& Furniture Ltd v National Trust Co (1990) 45 BCLR (2d) 99 at 112 per Lambert JA; Muschinski v Dodds (1985) 160 CLR 583 at 614 per Deane J; Re Omegas 16 F 3d 1443 (6 $6^{\text {th }}$ Cir. 1994); Maddaugh \& McCamus, The Law of Restitution ( $2^{\text {nd }}$ ed., 2004), pp.106-128; Rotherham, Proprietary Remedies in Context: A Study in the Judicial Redistribution of Property Rights (2002), pp.1232; Wright, The Remedial Constructive Trust (1998); Martin, Hanbury \& Martin: Modern Equity (16 ${ }^{\text {th }}$ ed., 2001), pp.301-304; Wright, "The Remedial Constructive Trust and Insolvency" in Restitution and Insolvency (Rose ed., 2000) 206; Birks, "Rights, Wrongs, and Remedies" (2000) 20 OJLS 1 at pp.9-19; Sir Peter Millett, "Restitution and Constructive Trusts" (1998) 114 LQR 399. 
normative and analytical functions. ${ }^{3}$ In assessing the utility of the proposed approaches at least four considerations therefore appear relevant. First, the chosen approach should permit adequate consideration and implementation of the appropriate normative concerns. In the context of specific relief such considerations must be considered in two different contexts: the justice of the claimant's entitlement as against the defendant; and the justice of that claim as against third parties claiming through the defendant. The latter consideration is relevant even where no third parties are apparent, not least because of the risk that important third party claims may not in fact be known by the court. Second, the chosen approach should facilitate the systematic organisation and presentation of the law, thereby enabling a reasonable measure of legal certainty, coherent development and synthesis. This requires the chosen approach to be logical and analytically sound. Third, the manner in which the constructive trust is portrayed should reflect realistically what the courts are doing in fact when they hold that the defendant is a constructive trustee of specific property. Care should be taken to avoid concepts which obscure more than they reveal. Finally, any conceptual revision, if required, should be the minimum necessary to achieve the desired results. This limitation, the principle of minimal conceptual disturbance, is necessary because the impact of a particular modification in one part of a legal system may effect changes to another, whether intended or not. ${ }^{4}$

This article examines the various ways in which the constructive trust is conceptualised, drawing upon judicial decisions and academic comments from England, the United States and the Commonwealth. It suggests that existing approaches in these jurisdictions are, to varying degrees, found wanting when measured against the criteria identified above. The orthodox Anglo-American approach, examined in Part II, turns out to be incoherent, fits poorly with related doctrines, and obscures important and complex normative concerns. The reasons for its persistence are ideological and historical. By contrast, courts and commentators in the Commonwealth have taken a more functional approach to the constructive trust. However, none of the suggested alternatives to the Anglo-American orthodoxy are entirely satisfactory. In Part III we see that a number of Canadian judges have attempted to develop a form of in specie relief that avoids unfair prejudice to third parties but, nevertheless, have continued to force such relief into the constructive trust mould. This, confusingly, gives us one concept with two distinct functions. Others have suggested that the constructive trust should allow the court to grant specific relief on whatever terms, and against whichever parties, that the court sees fit. This creates a range of problems that we might expect to find whenever judges are granted strong discretion. In Part IV we then see that Australian courts and commentators have developed approaches that are either excessively illogical or premised on wholesale changes that risk unintended interference elsewhere in the legal

3 On the nature of such concepts generally, see Hart, "Definition and Theory in Jurisprudence" in Essays in Jurisprudence and Philosophy (1983) 21; Kelly, "Legal Concepts, Logical Functions and Statements of Fact" (1968) 3 U Tas L Rev 43; Ross, "Tu-Tu” (1957) 70 Harv L Rev 812.

4 See Waldron, "Transcendental Nonsense' and System in the Law" (2000) 100 Colum L Rev 16. 
system. Moreover, the approaches do not deal effectively with the very problem that motivated them; namely, the creation of unwarranted and unintended priorities.

In light of these findings I suggest in Part V that a new analytical framework is required. This new framework would recognise both the constructive trust and a purely personal order to transfer specific property. The constructive trust would be conceptualised as a judicially imposed proprietary interest operating retrospectively, from the time of the facts giving rise to the claimant's cause of action, and would be imposed only where there is reason to grant the claimant the significant advantages that follow from the recognition or creation of an equitable proprietary interest. The purely personal order to transfer specific property, by contrast, would not recognise or create an equitable interest; it would simply confer on the claimant a purely personal right to the transfer of a particular asset. The claimant would be placed in a similar position to any other unsecured creditor and would not acquire an interest in the disputed asset until the defendant complied with his duty to transfer it. This would enable the courts to award a claimant a specific asset, rather than a money substitute, without the risk of creating unintended and unwarranted priorities. By reconceptualising the constructive trust and recognising a purely personal order to transfer specific property along these lines, normatively desirable results can be achieved within a framework that is coherent, rational and illuminating.

\section{Conceptions of the Constructive Trust as an "Institution"}

\section{(a) Anglo-american orthodoxy: the automatic vesting constructive trust}

Orthodox institutional theory conceptualises the constructive trust as arising by rule of law, independently of the court order, from the moment that the claimant's cause of action arises. The function of the court is simply to establish that the relevant facts did indeed occur and to recognise the claimant's pre-existing entitlement. ${ }^{5}$ A claimant does not ask a court to impose an institutional constructive trust; rather he alleges that one "already has come into existence as a result of the way in which the defendants obtained possession of their property". ${ }^{6}$ Facts occur upon which there is a simultaneous and automatic bifurcation of legal and equitable interest. The claimant's equitable proprietary interest arises once and for all, subject only to known modes of extinction, from this time. ${ }^{7}$ This "classical"

5 See the authorities cited in $\mathrm{n} .2$ above.

6 Kuwait Oil Tanker Company SAK v Al Bader, unreported, December 17, 1998, QBD (Moore-Bick J), reversed on other grounds [2003] UKHL 31. See also Re Jarvis [1958] 1 WLR 815 at 819 per Upjohn J.

7 See, e.g. Grant v Edwards [1986] Ch 638 at 652 per Mustill LJ; Turton v Turton [1988] Ch 542 at 552 per Nourse LJ, 554-555 per Kerr LJ; Sen v Hedley [1991] Ch 425 at 440 per Nourse LJ; Attorney General for Hong Kong v Reid [1994] 1 AC 324. Acceptance of this is typically combined with forceful rejection of the remedial constructive trust: Re Polly Peck International (in administration) (No2), n. 2 above; Metall und Rohstoff v Donaldson Lufkin Inc [1989] 3 All ER 14 at 57 per Slade LJ. But compare England v Guardian Insurance [2000] Lloyd's Rep IR 
conceptualisation predominates in English law. More surprisingly it has also taken root in the United States, although the constructive trust in this jurisdiction is formally declared to be remedial. ${ }^{9}$ Scott in particular is emphatic, arguing that " $[\mathrm{t}] \mathrm{h}$ e beneficial interest in the property is from the beginning in the person who has been wronged. The constructive trust arises from the situation in which he is entitled to the remedy of restitution, and it arises as soon as that situation is created". ${ }^{10}$ The role of the court, therefore, involves nothing more than the specific enforcement of the claimant's preexisting rights. The court order places property in the hands of the "proper and equitable owner". ${ }^{11}$

\section{(b) The problematic consequences of the automatic vesting approach}

\section{(i) Obscuring the relative merits of competing claims}

The conceptualisation of the constructive trust as autonomous, arising prior to the court's involvement and apparently existing separate from any judicial recognition, risks suffocating substantive justice and marginalising legitimate third party interests. It encourages judges to think that the court has no control over the outcome and obscures complex normative issues that require consideration. $^{12}$

Where the relevant factual conditions are present, it is said, a trust arises automatically "in the world beyond the court", ${ }^{13}$ creating in the claimant an equitable proprietary interest. It thus follows from the nature of the interest previously created that third parties are inevitably affected, with such consequences as priority on the defendant's insolvency appearing natural and self-evident. It is therefore easier for the court to deny responsibility for the impact that the constructive trust has on third parties as a result of the suggestive power of the notion that something real has previously come into existence, with pre-determined consequences. ${ }^{14}$

The apparent inevitability of the outcome is also bolstered by the power of property: at the time the court adjudicates on the dispute the claimant already owns the asset. The court cannot therefore order an alternative form of relief

404 (Thornton QC) (preparedness to consider a claim to a remedial constructive trust if the matter ultimately arose).

8 French v Mason [1999] FSR 597 at 603 per Pumfrey J.

9 The presentation of the constructive trust as automatically vesting is found in the Restatement and the leading texts: Scott \& Seavey (Reporters), Restatement of the Law of Restitution: Quasi-Contracts and Constructive Trusts (1937) s.160; Scott \& Fratcher, The Law of Trusts (4th ed., 1987 \& Supplements), Vol. 5, s.462; Pomeroy, Equity Jurisprudence (5th ed., 1941), Vol. 2, s.375.

10 Scott \& Fratcher, n.9 above, s.462.4.

11 United States v Fontana 528 F Supp 137 at 144-145 (SD. NY. 1981). See also Restatement, n.9 above, s.160, comment e.

12 See, e.g. the analysis of Browne-Wilkinson J, as he then was, in Re Sharpe [1980] 1 All ER 198.

13 Birks, "Proprietary Rights as Remedies" in Frontiers of Liability (Birks ed., 1994), Vol. 2, 214 at p.215.

14 See, e.g. Stone, "The Reification of Legal Concepts: Muschinski v Dodds" (1986) 9 UNSWLJ 63. 
and refuse to recognise the claimant's right, for to do so would be tantamount to an illegitimate judicial expropriation of property. The idea that something is already the property of the claimant thus exerts greater leverage than competing normative considerations that may suggest an alternative outcome. ${ }^{15}$

An unreflective acceptance of the idea that the constructive trust has an existence autonomous from its judicial recognition, particularly when coupled with axiomatic notions about property, therefore wields a powerful ideological force. Thus, some commentators suggest that priority on insolvency by way of constructive trust follows not because it is just, fair or merited but because "equity" has previously created a property right. Absent this pre-existing property right the award of priority on the defendant's insolvency would constitute an improper preference: ${ }^{16}$ the role of the court is portrayed as one of enforcing pre-existing property rights rather than establishing priorities between the claimant and the defendant's creditors. The constructive trust claimant's priority is simply a necessary, if regrettable, by-product of the earlier rights creation. ${ }^{17}$

This reasoning tends to conceal rather than reveal the relative merits of competing claims while simultaneously explaining away the impact of the remedy on third parties. ${ }^{18}$ To say that the claimant is entitled to an asset, with priority over unsecured creditors, because a constructive trust exists, is different to saying that a constructive trust exists because a court will order specific relief and confer priority over certain other interests. ${ }^{19}$ The latter formulation makes it clear that the consequences require justification and recognises that "constructive trust is the name we give to that decision, not

15 See, e.g. Cohen, "Transcendental Nonsense and the Functional Approach" (1935) $35 \mathrm{Col} \mathrm{L} \mathrm{Rev} 809$ at p.820 (identifying "property" as one of the "magic "solving words' of traditional jurisprudence"); Gray, "Property in Thin Air" [1991] CLJ 252 at p.305 (noting the "powerful and yet wholly spurious moral leverage" generated by appeals to "property"). For an illustration, see Birks, "Trusts Raised to Reverse Unjust Enrichment: The Westdeutsche Case" [1996] RLR 3 at p.14 (suggesting that the only good reason for a court to order assets to be transferred to the claimant is if they already belong to him).

16 See, in particular, Jennings \& Shapiro, "The Minnesota Law of Constructive Trusts and Analogous Equitable Remedies" (1941) 25 Minn L Rev 667 at pp.675676; Scott, n.9 above, s.462.4.

17 While equity may have created the property right on the basis of existing precedent, the precedent may be the product of historical accident rather than a carefully reasoned solution to the problem of priority. Constructive trusts evolved historically to resolve two-party disputes, with little overt concern or consideration for creditors' interests: Maitland, Equity: A Course of Lectures (1936), p.220; Waters, "The English Constructive Trust: A Look Into the Future" (1966) 19 Vanderbilt L Rev 1215 at pp.1216-1220. Scots lawyers reject the widespread adoption of the constructive trust on this ground. Why, they ask, should Scottish insolvency law be determined by the accidents of another jurisdiction? See Gretton, "Constructive Trusts" (1997) 1 Edinburgh L Rev 281 \& 408 at pp.410411.

18 Dawson, Unjust Enrichment: A Comparative Analysis (1951), pp.31-32; Lacy, "Constructive Trusts and Equitable Liens in Iowa" (1954) 40 Iowa L Rev 107 at pp.109-114; Sherwin, "Constructive Trusts in Bankruptcy" [1989] U Ill L Rev 297 at pp.311-313.

19 Cohen, n.1 5 above, pp.813-814. 
the reason for it". ${ }^{20}$ It is therefore less likely to propagate constructive trusts that have unjust consequences on the defendant's insolvency. Thus, where judges are asked openly to retrospectively impose equitable title to assets in favour of the claimant, creditors and supervening interests are at the forefront of their minds. A constructive trust is imposed, if at all, cautiously. ${ }^{21}$ By contrast, the first formulation appears to naturalise such consequences: ${ }^{22}$ the disputed asset already belongs to the claimant, not the defendant, therefore ordering its transfer has no impact on the defendant's creditors. ${ }^{23}$ It is therefore easier to lose sight of the essential policies that should limit the constructive trust's application.

\section{(ii) Logical deficiencies}

We also find that the automatic vesting constructive trust is a somewhat illogical judicial creation. For example, in some contexts an element of discretion is formally recognised as part of the decision to award a constructive trust, ${ }^{24}$ even though this is inconsistent with the automatic vesting conceptualisation. It makes no sense to characterise the interest under the constructive trust as arising automatically at the time of the facts because, if the interest is dependent on how a court exercises its discretion, it cannot arise independently of and prior to the judicial decision that creates it. ${ }^{25}$ Talk of discretion might, of course, be downplayed ${ }^{26}$ or passed off as

20 Dobbs, Law of Remedies - Equity - Damages - Restitution (1993), p.399, n.40.

21 See, e.g. Fortex, n.2 above, at 179-180 per Henry J; Chodar, n.2 above, at [57] (the interests of creditors and third parties are a "major and frequent obstacle to the grant of a proprietary remedy").

22 For a useful account of the ways in which legal concepts can make particular conclusions appear self-evident while avoiding discussion about the desirability of those conclusions, see Cohen, "The Value of Value Symbols in Law" (1952) 52 Col L Rev 893.

23 See, e.g. Scott, who avoids any reference to the relevant policy concerns. Scott reasons that the constructive trust arises at the time of the unjust enrichment, and for this reason the claimant is awarded priority, before demonstrating that the claimant's interest under a constructive trust vests automatically because the claimant can recover property in specie even though the wrongdoer is insolvent: Scott \& Fratcher, n.9 above, s.462.4, pp.323, 325.

24 E.g. where a constructive trust is imposed as the minimum equity to do justice in appropriate cases of proprietary estoppel, the determination of the minimum equity being formally portrayed as discretionary: see, e.g. Campbell v Griffin [2001] EWCA Civ 990 at [36] per Walker LJ; Griffiths v Williams (1977) 248 EG 947.

25 A broader conceptual inconsistency is also becoming apparent as some English courts resort to the separation of liability and remedy more generally in order to determine whether a constructive trust is appropriate. They recognise that remedy is not necessarily pre-determined by the nature of the obligation breached but rather follows from a search for what is factually the better solution to the facts before the court: see, e.g. Lord Napier \& Ettrick v Hunter [1993] AC 713 at 738 per Lord Templeman, 744 per Lord Goff (each providing reasons why a lien was a more appropriate remedy than a constructive trust, despite the existence of authority supporting the imposition of the latter). See also Ocular Sciences Ltd $\mathrm{v}$ Aspect Vision Care Ltd [1997] RPC 289 at 411-416, where Laddie J rejected explicitly the existence of a direct link between profitable breach of fiduciary obligation and constructive trust, opining that "the court should consider whether it is the appropriate remedy in the circumstances of the case". 
rhetoric. ${ }^{27}$ But while a broad or strong discretion may not exist, it is not always possible or desirable to eliminate discretion entirely, even in the face of a formal commitment to rules. ${ }^{28}$

A further logical deficiency is evident when one considers the link between the time at which the equitable interest apparently arises under the constructive trust and the time of the facts that determine the interest. A number of commentators suggest that logic requires the constructive trust to arise at the time of the events creating a cause of action in the claimant. ${ }^{29}$ However, facts occurring after the cause of action arose may be relevant to the decision to award or deny a constructive trust. ${ }^{30}$ This is true of constructive trusts arising in the context of specifically enforceable contracts for sale, ${ }^{31}$ even though the constructive trust is said to arise immediately upon completion of the contract. ${ }^{32}$ It is also true of estoppel cases, where supervening events may lead the court to either withhold the required relief altogether or grant relief of a different form or on different terms than it would have done if asked at an earlier stage. ${ }^{33}$ It now appears, moreover, that similar observations might be made in the context of quantifying parties' respective beneficial entitlements under a common intention constructive trust, at least in those cases where the parties' respective shares are not clear from what was done or said at the time the common intention was formed. ${ }^{34}$

26 See, e.g. Jennings $\mathrm{v}$ Rice [2002] EWCA Civ 159 at [43]-[44] per Walker LJ; Gardner, "The Remedial Discretion in Proprietary Estoppel" (1999) 115 LQR 438.

27 See, e.g. Edelman, "Remedial Certainty or Remedial Discretion in Estoppel After Giumelli" (1999) 15 JCL 179 (talk of discretion simply refers to rule-based discretion). For an alternative analysis, see Wright, "Giumelli, Estoppel and the New Law of Remedies" [1999] CLJ 476.

28 It is increasingly recognised that the difference between rules and discretion is one of degree and somewhat unstable, varying with time and context: see Sunstein, "Problems With Rules" (1995) 83 Cal L Rev 953; Schneider, "Discretion and Rules: A Lawyer's View" in The Uses of Discretion (Hawkins ed., 1992) 47. Any distinction between the institutional and remedial made on the basis of rulesdiscretion is therefore somewhat ephemeral: see Gardner, "The Element of Discretion" in Frontiers of Liability (Birks ed., 1994), Vol. 2, 186 at pp.193, 197 198.

29 See, e.g. Kull, "Restitution in Bankruptcy: Reclamation and Constructive Trust" (1998) 72 American Bankruptcy LJ 265 at p.287; Black, "Baumgartner v Baumgartner, the Constructive Trust and the Expanding Role of Unconscionability" (1988) 11 UNSWLJ 117 at pp.128-129.

30 Although this is often denied: see, e.g. Turton v Turton [1988] 1 Ch 542 at 552 per Nourse LJ.

31 See, e.g. Price v Strange [1978] 1 Ch 337.

32 Lysaght v Edwards (1876) 2 Ch D 499 at 506-507 per Lord Jessel MR, although as to the precise nature of the interest arising see Jerome $\mathrm{v}$ Kelly (Inspector of Taxes) [2004] UKHL 25, [2004] 1 WLR 1409 at [30]-[32].

33 For particularly notable examples, see Crabb v Arun DC [1976] Ch 179 at 189190 per Denning MR, 199 per Scarman LJ; Williams v Staite [1979] Ch 291 at 298-299 per Goff LJ, 300-301 per Cumming-Bruce LJ; Pascoe v Turner [1979] 1 WLR 431; Burrows v Sharp (1989) 23 HLR 82; Voyce v Voyce (1991) 62 P \& CR 290 at 296 per Nicholls LJ; Sledmore v Dalby (1996) P \& CR 196.

34 As Chadwick LJ noted recently, "there is no difference, in cases of this nature, between constructive trust and proprietary estoppel": Oxley v Hiscock [2004] EWCA Civ 546, [2004] 3 WLR 71 at [66]. See also Grant v Edwards [1986] Ch 638 at 656 per Browne-Wilkinson VC; Yaxley v Gotts [2000] Ch 162 at 176, 180 
In these instances the court will grant a share "which, in light of all the material circumstances (including the acts and conduct of the parties after the acquisition) is shown to be fair". ${ }^{35}$ Thus, each party will be:

"entitled to that share which the court considers fair having regard to the whole course of dealing between them in relation to the property. And in that context, 'the whole course of dealing between them in relation to the property' includes the arrangements which they make from time to time in order to meet the outgoings (for example, mortgage contributions, council tax and utilities, repairs, insurance and housekeeping) which have to be met if they are to live in the property as their home." 36

It follows that the claimant's beneficial entitlement will depend, in part at least, on facts occurring after the date on which the common intention was formed and detrimentally relied upon. It is, however, the date on which the common intention was detrimentally relied upon that the automatic vesting approach fixes the claimant's beneficial interest. ${ }^{37}$

We find, therefore, that in many cases facts which determine the availability or extent of the claimant's beneficial entitlement under a constructive trust can occur at a date later than its apparent date of birth. In these instances at least, logic suggests that the constructive trust must exist only from the date at which the factors determining the existence or extent of the beneficial interest crystallise; namely, at the date of court hearing. Any equitable proprietary interest "existing" from the time the claimant's cause of action accrued must be recognised as created retrospectively.

We also find problems where the constructive trust is contingent on the exercise of a power of election by the claimant. Thus, where the claimant

per Walker LJ; Chan Pui Chun v Leung Kam Ho [2002] EWCA Civ 1075 at [91][92] per Parker LJ. The apparent coalescence is not, however, universally accepted: see Fox, "Trusts of the Family Home: The Impact of Oxley v Hiscock" (2005) 56 NILQ 83 at 99-102.

35 Oxley v Hiscock [2004] EWCA Civ 546 at [66] per Chadwick LJ. Earlier cases had suggested that post-acquisition events were relevant because they served simply to demonstrate what shares must have been intended by the parties at the outset, but they did not themselves create or determine the entitlement: see Midland Bank v Cooke [1995] 4 All ER 562 at 574 per Waite LJ; Stokes v Anderson [1991] 1 FLR 391 at 400 per Nourse LJ.

36 ibid., at [69] per Chadwick LJ. See also Grant v Edwards [1986] Ch 638 at 657658 per Browne-Wilkinson VC; Drake v Whipp [1996] 1 FLR 826 at 831 per Gibson LJ; Cox v Jones [2004] EWHC 1486, [2004] 2 FLR 1010; Hurst v Supperstone [2005] EWHC 1309.

37 In Oxley v Hiscock, Chadwick LJ did not discuss the impact of his conclusions on the nature of the constructive trust, but recognised at [70] that "the courts have not found it easy to reconcile [the approach] with a traditional property-based approach." Elsewhere, it has been noted that an estoppel-based approach, involving the imposition of a constructive trust with retrospective effect, "is unlikely to find favour with English courts whose approach is to regard rights of property as fixed and ascertainable in advance and immutable": Hayton, Commentary \& Cases on the Law of Trusts and Equitable Remedies $\left(11^{\text {th }}\right.$ ed., 2001), p.352. 
seeks a constructive trust pursuant to the successful tracing of an asset into a substitute, situations arise in which the original asset remains identifiable in the hands of a third party, who took with notice, while the substitute is identifiable in the hands of the defendant. The claimant must therefore elect against whom he wishes to proceed. He cannot simultaneously own both the original asset and the substitute. ${ }^{38}$ Prior to the election, the claimant cannot therefore have a full equitable interest in the substitute asset. How, then, can a constructive trust "arise" prior to the date of election? The same question can be asked of cases where property passes pursuant to a voidable contract. Failure to rescind precludes a constructive trust claim, and the consequent equitable proprietary relief, ${ }^{39}$ on the ground that despite the impediment affecting the transfer the transferor nonetheless intended full legal and beneficial ownership to pass. ${ }^{40}$ The constructive trust cannot therefore "arise" at the time of the transfer ${ }^{41}$ because its existence is contingent on the subsequent avoidance by the transferee. The transferee is only "potentially a constructive trustee". ${ }^{42}$ If the equitable interest that arises pursuant to rescission is to have effect from the time of the initial transfer, this must be recognised as being retrospective. ${ }^{43}$

\section{(iii) Gross artifice}

Elsewhere, we find that explanations demanded by the automatic vesting approach, while logical, do not appear to reflect the reality. For example, where the defendant acquires a benefit from a third party in breach of fiduciary obligation, the principal may elect to adopt or reject the fiduciary's purchase. ${ }^{44}$ This appears inconsistent with the idea of a beneficial interest vesting automatically in the claimant upon the defendant's receipt because the claimant's interest is contingent upon a positive election. We are, however, told by the authorities that, upon the defendant's acquisition, the claimant immediately acquires a full equitable interest. Where the election is

38 Birks, "Mixing and Tracing" (1992) 45 CLP 69 at pp.89-98, developing more fully the views expressed in An Introduction to the Law of Restitution (1989, revised edition), pp.91-93, 393-394. Smith suggests simultaneous ownership is possible: The Law of Tracing (1997), pp.380-383. But see the compelling criticism of this view by Rotherham, n.2 above, pp.95-96.

39 See Twinsectra v Yardley [1999] Lloyd's Rep Bank 438 at 461 per Potter LJ; Halifax Building Society v Thomas [1996] Ch 219 at 226 per Gibson LJ; El Ajou v Dollar Land Holdings [1993] 3 All ER 717 at 734 per Millet J; Lonrho v Fayed (No 2) [1992] 1 WLR 1 at 11-12 per Millett J.

40 Collings v Lee [2001] 2 All ER 332 at 337 per Nourse LJ; Halley v Law Society [2003] EWCA Civ 97 at [53] per Carnwath LJ.

41 As claimed in Latec Investments v Hotel Terrigal Pty Ltd (1965) 113 CLR 265 at 290-291 per Menzies J (in the event of successful rescission "the conveyee holds, and has always held, as trustee"); Stump v Gaby (1852) 2 De G M \& G 623. See also Cope, Constructive Trusts (1992), pp.278-280.

42 Estates Realities v Wignall [1992] 2 NZLR 615 at 632 (Tipping J).

43 See Lonrho v Fayed (No 2), n.39 above, at 12. There, Millett J noted that it may well be "the beneficial interest in the property will be treated as having remained vested in him throughout" (emphasis added).

44 See Dean v MacDowell (1878) LR 8 Ch D 345 at 351 per James LJ. As a leading text puts the matter, in such cases the constructive trust is "a sword for the beneficiaries which may be sheathed if desired": Mowbray, Tucker, Le Poidevin \& Simpson, Lewin on Trusts (17 ${ }^{\text {th }}$ ed., 2000), p.447. 
positive the claimant simply takes that which, in equity, is already his; where the election is negative that act simply involves the making of a gift of the beneficial interest to the defaulting fiduciary. ${ }^{45}$ This is surely a perversion of words, if not intellectually dishonest. The "gift" is really nothing of the sort; it is merely a condonation of a breach of fiduciary duty.

\section{(iv) Restricting the availability of relief in specie}

The automatic vesting approach may also impact negatively on the general availability of specific relief. An important feature of the constructive trust is that it allows the claimant to take the very property that is the subject matter of the dispute. He is not left with an equivalent monetary substitute. Another important feature is that the constructive trust confers priority over the defendant's creditors and later equitable interests. The result of this is that, on occasion, the courts may refuse to extend specific relief by way of constructive trust to encompass the case at hand, where third parties are absent, for fear of binding a court hearing a future case, where third party interests are present. ${ }^{46}$ The problem arises because the constructive trust is assumed to create equitable property rights which arise necessarily at the time of the facts that fulfil the necessary conditions for its existence. Third parties claiming through the defendant are therefore bound of necessity whenever the relevant triggering facts are established. Consequently, the availability of specific relief outside the insolvency context may be limited, despite reasons other than priority for its award, ${ }^{47}$ for fear of forcing future courts to recognise the existence of inappropriate rights. While the problem could be avoided if the courts were prepared to take a more discretionary approach to the constructive trust, retaining the power to deny its availability where it would create an injustice, this would be inconsistent with the orthodox rejection of discretionary constructive trusts in English law. ${ }^{48} \mathrm{We}$ thus find a lacuna in equity's remedial armoury.

\section{(c) Why has the automatic vesting approach persisted?}

The automatic vesting conceptualisation has been rarely questioned in English law and, despite recent challenges, ${ }^{49}$ continues to represent the orthodoxy in the United States. ${ }^{50}$ Given the logical and practical deficiencies

45 For particularly strong reliance on this theory, see Cook v Evatt (No 2) [1991] 1 NZLR 676 at 696-697. The theory also appears in Cook v Deeks [1916] 1 AC 554 at 564, where the Privy Council established that the self-interested directors had no power to condone their breach and "make a present to themselves" of company property.

46 See, e.g. Klippert, Unjust Enrichment (1983), p.196 (priority advantage conferred by the constructive trust means that it cannot be made broadly available for fear of the incidental creation of unwarranted priorities).

47 On which see Goff \& Jones, The Law of Restitution (5 $5^{\text {th }}$ ed., 1998), pp.76-77.

48 See also the criticisms of the "limited flexibility" and "monolithic" remedial approaches below.

49 See, e.g. Re CRS Steam Inc. 225 BR 833 (Bankr. Mass. 1998); Re Dow Corning Corp 192 BR 428 (Bankr. Mich. 1996); US v BCCI Holdings (Luxembourg), SA 46 F 3d 1185 (DC Cir. 1995); Re Omegas Group Inc 16 F 3d 1443 (6 $6^{\text {th }}$ Cir. 1994).

50 See, e.g. Re McCafferty 96 F 3d 192 at 198 (6 $6^{\text {th }}$ Cir. 1996); Re Dameron 115 F 3d 718 (4 ${ }^{\text {th }}$ Cir. 1998); Re Leitner 236 BR 420 (Bankr. D. Kan. 1999). 
of this conceptualisation its persistence appears puzzling. Three reasons might explain its longevity.

\section{(i) Obscuring the judicial variation of property rights}

One explanation for the persistence of the automatic vesting approach is its use in obscuring departures from classical liberal understandings of property. The proposition that the judiciary has no power to engage in the nonconsensual redistribution of property rights permeates much of English law. ${ }^{51}$ However, some constructive trusts are incompatible with this orthodoxy. For example, the constructive trust of the bribe in Attorney General for Hong Kong $\vee$ Reid ${ }^{52}$ was redistributive: it did not arise as a result of the consent of the parties and it did not function to protect a pre-existing property right of the claimant. However, rather than acknowledge this the Privy Council reasoned that the constructive trust arose automatically upon receipt of the bribe, prior to the involvement of the court, by virtue of the maxim "equity considers as done that which ought to be done". The court did no more than simply recognise the claimant's pre-existing right. It thereby formally maintained the appearance that orthodox notions of property were not being violated while creating in fact a property right in the claimant de novo. ${ }^{53}$ The automatic vesting conceptualisation thus suppresses a reality that is subversive to the basic commitments of English law. Its function, as Rotherham points out, is "not so much practical as ideological". 54 It is, therefore, no coincidence to find movement away from the automatic vesting conceptualisation in those jurisdictions which have developed more instrumentalist understandings of property. In Canada, for example, it is now accepted that the courts can both recognise and create property rights by the imposition of a constructive trust. ${ }^{55}$

\section{(ii) The ideal of pre-legal rights}

The portrayal of the constructive trust as an automatically vesting entitlement also maintains congruence with the classical idea of pre-legal rights that derive from some privileged source of legitimacy. These ideals underpin the work of Professor Birks: the role of the judge is to find and apply the law, changing nothing except that which comes from a better understanding of what is there already. ${ }^{56}$ With such broader methodological commitments the automatic vesting conceptualisation of the constructive trust is perhaps

51 Rotherham, n.2 above, pp.34-40

52 [1994] 1 AC 324.

53 Rotherham, "Proprietary Relief for Enrichment by Wrongs: Some Realism About Property Talk" (1996) 19 UNSWLJ 378 at pp.396-397. See also Cook v Deeks, $\mathrm{n} .45$ above (opportunity acquired by directors from a third party in breach of fiduciary duty characterised as usurpation of the company's property).

54 Rotherham, n.2 above, p. 29.

55 See, e.g., Lac Minerals v International Corona Resources Ltd (1989) 61 DLR (4 $\left.4^{\text {th }}\right)$ 14 at 50-51 per La Forest J; Semiahmoo Indian Band v Canada (1997) 148 DLR $\left(4^{\text {th }}\right) 523$ at $559-560$ per Isaac CJ.

56 See, e.g. Birks, An Introduction to the law of Restitution (1989, revised edition), pp.23, 27 and "The End of the Remedial Constructive Trust?" (1998) 12 TLI 202 at pp.214-215. The similarities to the heavily criticised classical legal thought of late nineteenth century America are numerous: see, e.g. Grey, "Langdell's Orthodoxy" (1983) 45 U Pitt L Rev 1. 
inevitable. A constructive trust that arises automatically, prior to any judicial involvement, and which merely recognises the claimant's pre-existing entitlement, maintains congruence with the idea that the result follows from the application of a body of impartial universal principles established since time immemorial. It thus creates the impression that the court undertakes a passive declaratory role rather than an active and creative one. ${ }^{57}$

\section{(iii) The distorting influence of Scott and the Restatement}

It would, however, appear that these reasons do not explain adequately the longevity of the automatic vesting approach in the United States. There, the realist onslaught of the late nineteenth and early twentieth centuries led to the emergence of an instrumental concept of law and property which make the persistence of the automatic vesting conceptualisation superficially puzzling. ${ }^{58}$ But such persistence does not defy all explanation. While classical visions of property and the role of the judiciary were historical stimuli for the conceptualisation, its persistence has for some time owed more to the powerful stabilising effect of the Restatement of Restitution and Scott's Law of Trusts, both of which have played a pivotal role in American understandings of the constructive trust. ${ }^{59}$

Scott was a joint reporter of the Restatement, published in 1937, and sole author of the first edition of his influential treatise. ${ }^{60}$ Both works conceptualise the constructive trust as an automatically vesting entitlement, arising prior to the involvement of the court. This is partially explicable by Scott's classical orthodox background. Scott wrote towards the end of an era characterised by a firm belief in the inviolability of property, universal principles of common law and the felt need to reveal the law's hidden

57 Note, however, that the declaratory theory of law has been killed off judicially: Kleinwort Benson v Lincoln City Council [1999] 2 AC 349.

58 On the emergence of an instrumental concept of law and its stimuli, see generally Horwitz, The Transformation of American Law 1870-1960: The Crisis of Legal Orthodoxy (1992). In outline, the instrumentalist approach involved: (i) a rejection of the belief that cases could be decided without controversy by reference to abstract legal principles and concepts; (ii) the recognition that judges made rather than discovered law; and (iii) the recognition that judge-made law was an instrument of social policy, to be made and applied purposively in accordance with such policies. It was equally accepted that property rights were necessarily shaped and limited by judges balancing competing policies and interests, with each stick in the owner's bundle of rights necessarily imposing burdens on nonowners. See, e.g. Singer, "Legal Realism Now" (1988) 76 Calif L Rev 467; Horwitz, Fisher \& Reed, American Legal Realism (1993); Cohen, "Property and Sovereignty" (1927) 13 Cornell LQ 8; Hohfeld, "Some Fundamental Legal Conceptions as Applied in Judicial Reasoning" (1913) 23 Yale LJ 16; Hohfeld, "Fundamental Legal Conceptions as Applied in Judicial Reasoning" (1917) 26 Yale LJ 710.

59 Both have been cited heavily for the automatic vesting approach: see the cases cited in Scott \& Fratcher, n.9 above, s.462.4. Scott in particular is often cited as authority where the effect of timing is to confer priority over the defendant's creditors or intervening lien holders: see, e.g. Re General Coffee Corp $828 \mathrm{~F} 2 \mathrm{~d}$ 699 (11 ${ }^{\text {th }}$ Cir. 1987) (insolvency); United States v Fontana, n. 11 above (federal tax lien).

60 Scott, The Law of Trusts (1st ed., 1939). 
structure through conceptual ordering. ${ }^{61}$ Moreover, the formative years of his legal education were spent at Harvard, the heartland of Langdellian casebook method which taught that the law could be discovered scientifically and arranged schematically as a set of logical propositions. ${ }^{62}$ Equally, the early Restatements represented an instinctive reaction by the legal establishment to the realist movement and its criticism of Langdellian legal science. They attempted to refute claims about the legislative role of the judge while simultaneously reasserting the idea of impartial, self-executing laws. ${ }^{63}$ A conceptualisation that bolstered these ideals was therefore understandable. The problem is that Scott's treatise and the Restatement have been perceived as authorities of timeless value, crystallising the cases into properly derived rules that are simply there to be applied. Thus, it has been noted that restatements of law were often treated in a similar way to legislative codes. So long as authority did not lie squarely against the rules they promulgated, they could be followed by judges "exactly as they would follow a statute". ${ }^{64}$ Much the same might be said of Scott's treatise: it became almost too authoritative to challenge. Consequently, both authorities continued to exert an influence that retarded change in light of new understandings about the nature of property, the judicial function, and the efficacy and fairness of equitable property rights on insolvency. ${ }^{65}$ In the United States, the persistence of the automatic vesting conceptualisation is therefore illustrative of a broader problem created by the treatise tradition and restatements of law.

\section{(d) The constructive trust as automatically retrospective in effect}

While rejecting the notion of the remedial constructive trust Tony Oakley, author of the leading English text on the subject, has formulated an alternative conceptualisation that differs from the orthodoxy in at least one fundamental respect: a court order is necessary for the constructive trust to take effect. ${ }^{66}$ He thus talks of the "imposition" rather than "recognition" of a constructive trust. This conceptualisation sits a little uneasily with the idea of institutional trusts. However, Oakley openly rejects discretionary remedial approaches $^{67}$ and views the consequences of the constructive trust as monolithic. ${ }^{68}$ Moreover, he characterises the interest of a potential constructive trust claimant who has yet to secure a declaration of his interest

61 Rotherham, n.2 above, pp.49-51, 57-59. See also Grey, n.56 above.

62 See Waters, "The Role of the Trust Treatise in the 1990s" (1994) 59 Mo L Rev 121 at p.124.

63 Gilmore, The Death of Contract (1974), pp.58-59.

64 Gilmore, "Legal Realism: Its Cause and Cure" (1961) 70 Yale LJ 1037 at p.1044.

65 Although see the more enlightened contemporary opinion of the constructive trust as a priority creating mechanism: Re Stotler \& Co 144 BR 385 at 388 (ND. Ill. 1992); Re Morken 182 BR 1007 (Bankr. D. Minn. 1995); Foos 183 BR 149 (Bankr. ND. Ill. 1995); Re North American Coin \& Currency Ltd 767 F 2d 1573 ( $9^{\text {th }}$ Cir. 1985). See also the authorities cited in $n .49$ above.

66 Oakley, Constructive Trusts ( $3^{\text {rd }}$ ed., 1997), pp.5-6.

67 Oakley also appears on occasion to suggest that the equitable interest arises automatically and a court order is simply a formality: see n.69 below.

68 Although this may be subject to limited exceptions: see $n .73$ below. 
as "a full equitable interest". ${ }^{69}$ While consistent with the case law, this appears to be a restatement of the automatic vesting approach and inconsistent with the requirement of a court order before the constructive trust can take effect: a constructive trust that is judicially imposed surely cannot exist prior to its imposition.

The view that Oakley purports to adopt derives from Bogert's treatise on American trust law. ${ }^{70}$ However, in this work Bogert flatly denies that the claimant holds the beneficial interest from the outset. He suggests that when constructive trust claimants seek the imposition of a constructive trust, "they may be treated as if they had been from the beginning the owners of such estate or interest." 71 Thus, the constructive trust is fully retrospective; for all practical purposes it is deemed to have arisen at the time of the facts giving rise to its imposition. ${ }^{72}$ It follows that, while a court order is necessary for a constructive trust to take effect, this in no way affects the priorities between the constructive trust claimant and third parties.

\section{(e) The utility of automatic retrospectivity in English law}

While the requirement of curial declaration for a constructive trust to operate avoids reifying the constructive trust in the sense of treating it as something that exists independently of the decision to impose it, the approach continues to treat the claimant's priority over general creditors as an inevitable incident of a constructive trust claim. Once the requisite operative facts are established the requirement of a court order is nothing more than a formality. ${ }^{73}$ Oakley thus states that it is because the constructive trust takes effect at the moment of the conduct giving rise to its imposition, and hence creates an equitable proprietary interest at this time, that it is binding on the

69 Oakley, "Proprietary Claims and Their Priority on Insolvency" [1995] CLJ 377 at p.424; Oakley, Parker \& Mellows: The Modern Law of Trusts ( $8^{\text {th }}$ ed., 2003), p.833.

70 Bogert \& Bogert, The Law of Trusts and Trustees ( $2^{\text {nd }}$ ed., 1978), s.472.

71 ibid. In the same section Bogert asserts that the court order decreeing the constructive trust establishes the defendant as constructive trustee "as of the date of his wrongful acquisition".

72 This conceptualisation has received some judicial support in the United States: Re Dow Corning, n.49 above, at 436; Bly v Gensmer 386 NW 2d 767 at 769 (Minn. App. 1986); Healy v CIR 345 US 273 at 282-283 (1952); International Refugee Organization v Maryland Dry Dock Co 179 F 2d 284 at 287 (4th Cir. 1950); Stoehr v Miller $296 \mathrm{~F} 414$ at $426-427$ ( $2^{\text {nd }}$ Cir. 1924).

73 Oakley does allude to the fact that the court has power to vary the general rule with respect to timing: "The Precise Effects of the Imposition of a Constructive Trust" in Equity and Contemporary Legal Developments (Goldstein ed., 1992) 427 at pp.437-438. This is difficult to reconcile with Oakley's rejection of the remedial constructive trust and his support for the institutional approach. However, Oakley views this power as of limited scope. For example, it is not deemed appropriate in the context of constructive trusts imposed on profiting fiduciaries. Indeed, it appears that Oakley envisages the power to be limited to family property disputes and novel cases. He thus appears to view it as consistent with institutional theory because the limited exceptions "merely re-emphasise the universality of the general rule": n.66 above, p.6. 
trustee in bankruptcy. ${ }^{74}$ Priority over creditors is thus portrayed as natural, inevitable and apparently uncontroversial. That the constructive trust takes effect at the time of the conduct giving rise to its existence is, however, a conclusion, not a justification. Rather than enter into discussion of the merits of priority, Oakley thus adopts circuitous reasoning to explain away the impact of the constructive trust on the defendant's insolvency.

The dominant motive behind the conceptualisation appears to be a concern over taxation: if a constructive trust exists irrespective of whether the beneficiary ever seeks a court order to compel the defendant to convey the property, the claimant may be subject to tax liability for property which he has never claimed and never enjoyed. ${ }^{75}$ However, to this extent the emphasis on timing of creation appears an unnecessary complexity and only partially successful. While the approach may prevent the liability to tax of an unsuspecting claimant who has not sought to enforce a potential constructive trust claim, it appears that the constructive beneficiary who does enforce will become liable to tax for the period in which he has not enjoyed the property: once enforced the constructive trust is effective from the date of the relevant conduct. The claimant is therefore deemed to have owned the property in the interim and, as the beneficial owner, is liable to tax. The only way around this would be to make a sensible policy decision not to tax the claimant for such a period. This does not depend on the precise conceptualisation adopted. ${ }^{76}$ In the United States, for example, the identification of money as taxable income has been held to turn on whether the recipient has "such control over it that, as a practical matter, he derives readily realizable economic value from it". ${ }^{77}$ The constructive trust theory adopted by the court therefore "in no way determines the allowability of the claim". ${ }^{78}$ A similar approach was adopted in Canada at a time when the automatic vesting approach dominated. ${ }^{79}$ More recently, it was established that where the developing remedial constructive trust would frustrate statutory provisions or create practical problems it would be treated as not within the legislative intent of the relevant taxation provision. ${ }^{80}$

Oakley's willingness to adapt the constructive trust in light of the apparent injustices that would otherwise be created in the context of taxation is telling. The most pressing, important and directly relevant concern for the

74 Oakley, n.66 above, p.5. Presumably, for this reason, a constructive beneficiary who seeks to enforce his claim to the property will also become liable to tax as of that date, even though he has not enjoyed the benefit of the property in the interim.

75 See Oakley, n.73 above, p.437; Oakley, n.66 above, p.6.

76 See, e.g. Glover, "Taxing the Constructive Trustee: Should a Revenue Statute Address Itself to Fictions?" in Trends in Contemporary Trust Law (Oakley ed., 1997) 315.

77 James v US 81 S Ct 1052 at 1055 (1960); Rutkin v US 343 US 130 at 137 (1952).

78 In the Matter of Diversified Brokers 355 F Supp 79 at 89 (ED, Miss. 1973). See

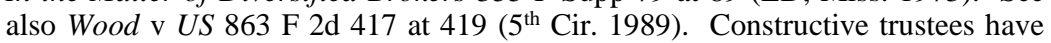
therefore been liable to tax for the period in which they had dominion and control over the property, regardless of the constructive trust theory adopted: see Healy v CIR 345 US 278 at 282-283 (1952) (automatic retrospectivity); First National Bank of Miami v US 235 F Sup 331 (SD. Fla. 1964) (automatic vesting theory).

$79 R$ v Poynton (1972) DTC 6329.

80 Karavos v Canada (1995) 57 ACWS (3d) 876; Nelson v NMR (1991) DTC 37 at 43. 
constructive trust is not taxation but the extent to which its imposition justifiably affects innocent third parties. However, it is this very issue that Oakley strains to avoid, reflecting the traditional reluctance of English law to engage openly in this question. ${ }^{81}$

\section{Conceptions of the Constructive Trust as a "Remedy"}

\section{(a) Judicial conceptions of the constructive trust as a remedy in Canada}

Consideration of the remedial constructive trust in Canada takes place in the context of two general developments. First, the courts have increasingly recognised that the constructive trust is "both blunt and powerful with the result that important third party interests can be too easily compromised". ${ }^{82}$ In particular, there has arisen considerable disquiet over the impact of the constructive trust on creditors ${ }^{83}$ and purchasers of the disputed property or an interest therein. ${ }^{84}$ Second, following the development of a general cause action in unjust enrichment, the courts have separated the consideration of liability from that of remedy. ${ }^{85}$ Once liability is established, the court is required to make a context specific evaluation of the most appropriate response to the unjust enrichment in question, taking into account the precise facts of the case as they present themselves at the date of the court hearing. ${ }^{86}$ Following these developments there has been a lack of unanimity about the most appropriate way to conceptualise the constructive trust.

In Rawluk $\mathrm{v}$ Rawluk Cory J, speaking for the majority, expressed complete agreement with Scott's automatic vesting approach and opined that "a property interest arising under a constructive trust can be recognised as having come into existence not when the trust is judicially declared but from the time when the unjust enrichment first arose". ${ }^{87}$ However, as we will see, Cory $\mathbf{J}$ appears to contradict this statement later in his judgment. Moreover, a continuing commitment to the automatic vesting approach is difficult to

81 See, e.g. Sir Peter Millett, "Remedies: The Error in Lister \& Co v Stubbs" in Frontiers of Liability (Birks ed., 1994), Vol.1, 51 at p.52 ("Either the plaintiff is entitled to a proprietary remedy or he is not. If he is then the insolvency of the defendant is not a sufficient reason for withholding it from him.")

82 Re 512760 Ontario Inc (1992) 91 DLR $\left(4^{\text {th }}\right) 719$ at 731 (Adams J). See also LeClair v LeClair (1998) 159 DLR $\left(4^{\text {th }}\right) 638$ at 651 per Ryan JA.

83 See, e.g. Soulos v Korkontzilas (1997) 146 DLR $\left(4^{\text {th }}\right) 214$ at 227, 230 per McLachlin J; Bedard v Schell (1987) Sask R 71 at 74-75 (Gerein J); CDIC v Principal Savings \& Trust Co (1998) 224 AR 331 at 337-341 (Belzil J).

84 See, e.g. Rawluk v Rawluk (1990) 65 DLR (4 $\left.{ }^{\text {th }}\right) 161$ at 188,191 per McLachlin J, exhibiting particular concern over the creation of invisible and unregistered or unregistrable interests in land.

85 Sorochan v Sorochan (1986) 29 DLR $\left(4^{\text {th }}\right) 1$ at 7 per Dickson CJ. See Waters, "Liability and Remedy: An Adjustable Relationship" (2001) 64 Sask L Rev 429.

86 A similar remedial approach is adopted for wrongs: see Cadbury Schweppes v FBI Foods [1999] SCR 142; Lac Minerals, n.55 above, at 50-52 per La Forest J.

87 n.84 above, at 176, citing Oosterhoff \& Gillese, Text, Commentary and Cases on Trusts (3rd ed., 1987), p.579 and Scott \& Fratcher, n.9 above, s.462.4. This conceptualisation does not appear to have been entirely ruled out in later cases: see Ellingsen v Hallmark Ford Sales Ltd (2000) 190 DLR $\left(4^{\text {th }}\right) 47$ at 70 per Lambert JA. 
reconcile with the increased concern for subsequent third party interests. This concern appears to require a power to deny a constructive trust where, all other things being equal except the appearance of third party interests, a constructive trust would have been awarded. ${ }^{88}$ According to the automatic vesting approach, however, the subsequent appearance of third party interests is an irrelevant consideration; third parties are bound necessarily by the earlier equitable interest created by the constructive trust. ${ }^{89}$ The approach is also difficult to reconcile with the separation of liability and remedy: how can the constructive trust arise concurrently with liability if factors that determine its appropriateness, including those arising in the interim, are the subject of discretionary consideration as at the date of trial?

Further interpretations of Rawluk, consistent with remedial thinking, are possible. ${ }^{90}$ Following his apparent agreement with Scott, Cory J quoted with approval the dictum of Lord Denning MR that a constructive trust "may arise at the outset, when the property is acquired, or later on, as the circumstances may require". ${ }^{91}$ In light of this, he suggested that "even if it is declared by a court after the parties have already separated, a constructive trust can be deemed to have arisen when the duty to make restitution arose". ${ }^{92}$ This appears to suggest that the constructive trust arises only when declared but the date from which it operates is a different matter. Two possible alternatives have emerged.

\section{(i) Limited flexibility: prospective or retrospective operation}

We might interpret the words of Cory $\mathrm{J}$ in Rawluk as indicating that, once a constructive trust is identified as the most appropriate remedy, it may be given either retrospective or prospective effect. ${ }^{93}$ Where a constructive trust is declared to operate retrospectively it will take effect from the moment that the claimant's cause of action accrued, and the consequences that follow from the creation of an equitable proprietary interest will run from this time. Where the constructive trust is declared to operate prospectively the

88 See, e.g. Peter v Beblow (1993) 101 DLR (4 $\left.4^{\text {th }}\right) 621$ at 640 , where Cory J noted that where the constructive trust would unfairly affect bona fide third party interests it would not be awarded.

89 It might be argued that the constructive trust can vest automatically but the court may not enforce the trust if to do so would create an inequitable result, such as the creation of unwarranted priorities: Shearer v Barnes 118 Minn 179 at 188 (1912). For criticism of such an approach, see the discussion of the merits of Muschinski v Dodds (1985) 160 CLR 583, below.

90 For a further inconsistent interpretation, see Stirling v Buck (1993) ACWS 1293, where Murphy J interpreted Cory J's comments as meaning that the constructive trust "arises at the time the unjust enrichment arises but the court, in declaring such a trust, can declare it effective either from the date it arose or from the date of the court order". This continues to vest the constructive trust with institutional characteristics and is akin to the narrow interpretation of Muschinski v Dodds, considered below.

91 Hussey v Palmer [1972] 3 All ER 744 at 747. On the mistaken interpretation of this dicta, see below.

92 n.84 above, at 176 (emphasis added).

93 The words of Cory J were that the constructive trust "can be deemed to have arisen when the duty to make restitution arose". They were not that it will be deemed to have arisen when that duty arose. 
claimant's equitable proprietary interest will take effect only from the date of judgment. This interpretation appears consistent with the influential dissent in Rawluk by McLachlin J, who commented:

"When the court declares a constructive trust, at that point the beneficiary obtains an interest in the property subject to the trust. That property interest, it appears, may be taken as extending back to the date when the trust was 'earned' or perfected. In Hussey v Palmer....Lord Denning postulated that the interest may arise at the time of declaration or from the outset, as the case may require." ${ }^{94}$

In fact, all that Lord Denning postulated in Hussey ${ }^{95}$ was that the relevant conduct which makes it unconscionable for a defendant to retain property may occur post-acquisition as well as pre-acquisition. ${ }^{96} \mathrm{He}$ made no suggestion that the Court could vary the time at which the interest arises. However, for present purposes the correct interpretation of Hussey is not as important as the meaning to which McLachlin $\mathrm{J}$ attributed it. She was clearly of the opinion that Hussey supported the inference that an unjust enrichment constructive trust ${ }^{97}$ would arise only if and when declared, and then operate either retrospectively or prospectively.

\section{(ii) Monolithic operation: deemed existence from time of unjust enrichment}

Some courts view Rawluk as establishing the narrower proposition that, while the court must first determine whether the imposition of a constructive trust is appropriate, once imposed it operates as if it had arisen at the time the claimant's cause of action arose. ${ }^{98}$ Thus, in Rawluk Cory $\mathrm{J}$ said:

"If the court is asked to grant such a remedy and determines that a declaration of constructive trust is warranted, then the proprietary interest awarded pursuant to that remedy will be deemed to have arisen at the time when the unjust enrichment first occurs." $" 99$

This conceptualisation was adopted by Ryan JA in LeClair v LeClair. ${ }^{100}$ By his will $\mathrm{J}$ devised his estate equally between his wife, $\mathrm{T}$, and his son, R. An apartment held solely by $\mathrm{J}$ but maintained and improved by $\mathrm{T}$ comprised $90 \%$ of the value of the estate. After J's death T claimed that her financial and non-financial contributions entitled her to an interest in half of the

94 n.84 above, at 185.

95 [1972] 3 All ER 744.

96 A view consistent with the judgment of Lord Diplock in Gissing v Gissing [1971] AC 886 at 905-906. Elsewhere, Lord Denning was of the opinion that the constructive trust arose upon the facts that so affected the defendant's conscience that he could not take free of the claimant's rights. See, for example, Binions v Evans [1972] Ch 359 at 368.

97 Her comments were explicitly limited to the constructive trust developed as a response to unjust enrichment: $\mathrm{n} .84$ above, at 185 .

98 See, e.g. King v Harris (1995) NBR (2d) 161; Barnebe v Touhey (1994) OR (3d) 370.

$99 \mathrm{n} .84$ above, at 177.

100 (1998) 159 DLR (4 $\left.{ }^{\text {th }}\right) 638$. 
apartment by way of constructive trust and that this share did not therefore form part of J's estate at his death. It was, however, accepted that J would have drawn his will differently had he been aware of T's claim. If, at his death, $\mathbf{J}$ was therefore found to have held a half share in the apartment on constructive trust for $\mathrm{T}, \mathrm{T}$ would have received an unintended windfall to the detriment of the innocent R. Ryan JA held that, while an unjust enrichment claim was established, the apartment was not automatically subject to a constructive trust prior to J's death. The court first had to determine that a constructive trust was appropriate and in this case it was not, both for the reasons stated and because the unjust enrichment had been appropriately remedied by the terms of the will which conferred on $\mathrm{T}$ a half share in the estate. Ryan JA stated:

"Cory $\mathrm{J}$ [in Rawluk] addressed the question whether, once a court declares a constructive trust, the interest arises at the time of judicial declaration, or as of the time of the unjust enrichment. His answer was that it arises at the time of the unjust enrichment. However, contrary to the appellant's argument in this case, this passage does not negate the need for a court to first determine whether an unjust enrichment occurred and whether the appropriate remedy would be a constructive trust." 101

The conceptualisation is therefore similar to Bogert's, although the separation of liability and remedy and general judicial awareness of the position of third parties permits greater emphasis on the justice of the outcome. ${ }^{102}$ The developing approach in New Zealand is also comparable. There, a finding of unjust enrichment or unconscionability triggers the court's discretionary determination of the most appropriate remedy. ${ }^{103} \mathrm{~A}$ constructive trust resulting from the exercise of this discretion can arise only when declared but will be backdated to the time the cause of action arose, to the detriment of creditors and those with later equitable interests. ${ }^{104}$ It will be imposed, therefore, only where such detriment is warranted or such creditors and later interests are absent. ${ }^{105}$

\section{(b) The utility of the approaches}

Both the "limited flexibility" and "monolithic" approaches are clearly of some merit, not least because they create a remedial framework within which specific relief can be granted without necessarily prejudicing third parties. It is recognised that the constructive trust does not simply enforce pre-existing property rights but rather operates to establish priorities between the claimant and other parties. ${ }^{106}$ Thus, claimants are conferred priority over the defendant's creditors "by means of (and not by reason of) their having a

101 ibid., at 648

102 See, e.g. ibid. at 651 and contrast to the treatment of the automatic retrospective approach by Oakley, who continues to view priority as an inevitable incident of the constructive trust.

103 See Chodar, n.2 above, at [42]

104 Fortex, n.2 above, at 175-177 per Tipping J, 179-180 per Henry J (referring to the creation of a "backdated proprietary interest").

105 For an illustration of the latter, see Chodar, n. 2 above.

106 See, in particular, Barnabe v Touhey, n.98 above, at 378-379. 
proprietary interest". ${ }^{107}$ Moreover, the approach makes it difficult for a court to ignore other potential injustices created by the operation of the constructive trust because its portrayal as arising only when declared emphasises judicial responsibility for the justice of the outcome. This is more consistent with contemporary judicial attitudes in those Commonwealth jurisdictions which embrace the creative nature of the judicial function. ${ }^{108}$ Indeed, without this change in legal culture it is difficult to see how the constructive trust could develop along these lines.

One might, however, question the extent to which either approach would effectively safeguard third party interests. The monolithic approach recognises that in some instances specific relief conferring general priority is warranted while in others it is warranted only to the extent third parties are not affected. In the former class of case the imposition of a constructive trust, with its retrospective effect, naturally achieves the required result. In the latter class of case the court must ensure that no third party interests are present before the constructive trust is imposed. At this point difficulties emerge because subsequent interests in or over the disputed property may not always be apparent and the solvency of the defendant may be unknown or difficult to ascertain. The defendant is the person most likely to hold the relevant information about the state of his solvency, yet least likely to make it available to the court: ${ }^{109}$ it is irrelevant to his liability and there may be legitimate business reasons for his not wanting to disclose such information publicly. To avoid unintended priorities it might be suggested that it will be inappropriate to award a constructive trust without "complete information". 110 However, this requirement may do no more than simply provide further incentive to the defendant to withhold relevant information in order to avoid being called upon to account for his gain in specie.

A prospectively ordered constructive trust which takes effect from the date of judgment would not confer priority over earlier equitable proprietary interests, including those created in the interim between the time at which the claimant's cause of action accrued and the date of judgment. However, prospective effect would not necessarily prevent the creation of unintended priorities over unsecured creditors. This may occur because a prospective

107 Evans, "Property, Proprietary Remedies and Insolvency: Conceptualism or Candour?" (2000) 5 Deakin L Rev 31 at p.44.

108 See, e.g. the extra-judicial writings of Kirby, Judicial Activism (2004); Mason, "Equity's Role in the Twentieth Century" (1997-8) 8 KCLJ 1; McLachlin, "The Role of Judges in Modern Commonwealth Society" (1994) 110 LQR 260; McHugh, "The Law-Making Function of the Judicial Process" (1988) 62 ALJ 16; La Forest, "Some Impressions on Judging" (1986) 35 U of New Brunswick LJ 145. Justices La Forest and McLachlin in particular have been influential in the development of the constructive trust in Canada, as has Mason J in Australia: see Lac Minerals, n.55 above, at 44-52; Rawluk, n.94 above and accompanying text; Soulos, n.83 above, at 221-232; Hospital Products v USSC (1984-5) 156 CLR 41 at $110-115$.

109 See, in particular, Chodar, n.2 above, where the defendant refused to submit information regarding his solvency. Glazebrook $\mathrm{J}$ imposed a remedial constructive trust - something she would not have done had the defendant been insolvent - having considered evidence on the matter that was "vague and unparticularised".

110 CDIC v Principal Savings \& Trust Co (1998) 224 AR 331 at 341. 
constructive trust would confer priority over general creditors in those presumably not uncommon situations in which the defendant is made insolvent by the court finding against him.

One might also question the appropriateness of forcing into the constructive trust mould specific relief that does not bind third parties. By interposing discretion between the facts creating liability and the decision to impose the constructive trust the constructive trust appears a unitary concept: certain facts create a discretionary determination of its availability and, once available, it confers on the claimant a property right. However, in those situations in which relief will be awarded only to the extent third parties are not affected, the imposition of a constructive trust appears nothing more than a misleading label to denote what is akin to a personal order to transfer property. This appears distinct from the idea of the constructive trust - a "proprietary concept" by which the claimant "is found to have an interest in property". 111 Were the in personam nature of the obligation created by the order openly recognised, there would be no risk of the creation of unintended priorities. Being a personal obligation, the claimant would be left to enforce judgment in the same way as other creditors with personal claims against the insolvent. The constructive trust, as a proprietary concept, could then be left intact to refer only to those situations where it is appropriate for the claimant to take the advantages which follow from the recognition or creation of an equitable proprietary interest.

Acknowledging this may bring with it a number of benefits. First, it may contribute to the rational development of the law because it assists the schematic or taxonomic presentation of the subject, whether that taxonomy is a taxonomy of rights ${ }^{112}$ or a taxonomy or remedies. ${ }^{113}$ Second, we avoid the confusion that follows from the use of one term to refer to two distinct remedies with different intended consequences. Third, it enables us to remove confusing trust nomenclature in those instances where a defining element of a trust - enforcement of interest against third parties - is absent. Fourth, the recognition that one species of "constructive trust" does not affect third parties resolves the difficulties created by the need to inquire into the liquidity of the defendant before awarding relief.

\section{(c) The constructive trust of tomorrow: the pure remedial approach.}

Some go further than the Canadian courts and suggest that greater flexibility is required to achieve justice. Most notably Professor Waters champions a

111 These being the characteristics of the constructive trust in Canada, as stated in Peter v Beblow, $\mathrm{n} .88$ above, at 649 per McLachlin J.

112 As propounded by Birks, n.2 above, in which case the constructive trust and the personal order would reflect two different responses in the second measure of restitution.

113 As propounded by, e.g. Wright, "Wrong and Remedy: A Sticky Relationship" [2001] SJLS 300, in which case the personal order would represent a new remedy and take its place alongside the constructive trust and other potentially available remedies, to be selected according to criteria of appropriateness once liability is established. See also Waye \& Wright "Trial Strategy When Selecting a Remedy From the Remedial Smorgasbord” (1998) 17 Australian Bar Rev 263. 
"pure remedial constructive trust", ${ }^{114}$ the court retaining maximal flexibility as to its operation and content. Its precise effects will thus vary with the circumstances of each case and the conduct of each creditor: ${ }^{115}$ the order may give effect to a constructive trust from the time of the unjust enrichment, the time of the court order, some interim date, or some future date; and the order may be granted on whatever terms that the court sees fit. ${ }^{116}$

"[The courts could] ensure that only particular third parties are affected by the in rem restitution. A[n] order might be given as against one defendant, but not against another, or it might be given as against both but with the content of the order varied at the discretion of the court to meet the equities of the situation, as far as each defendant is concerned. It would affect third parties not before the court by creating such priorities as the court states in the order ... As there is no reason in my opinion why every chargee or lienholder of the assets in dispute who has acquired his charge or lien between enrichment and court order should automatically be relegated to a priority behind the claimant of the assets for unjust enrichment, so in my opinion there is no reason why every unsecured creditor of the enriched party should be so relegated." 117

The merits of the claim of each individual potentially affected by the in rem relief granted are therefore considered.

\section{(d) The utility of pure remedial theory}

The concern for greater individualised justice and fairness to third parties is laudable. In theory, the model permits the award of specific relief on terms that are always fair and just to the defendant, the claimant, and any third parties. The approach is not open to the criticism that it represents an illegitimate erosion of the parri passu principle where the defendant is insolvent. This principle does nothing more than affirm that which is selfevident: parties standing in positions of relative equality are to be treated equally. ${ }^{118}$ The pure remedial approach simply rests on a more refined analysis of relative equality. It is, however, problematic for other reasons.

First, it is difficult to imagine circumstances in which such a broad discretion to discriminate between individual creditors is necessary. And even were we to accept in principle that such circumstances might arise, it would be

114 Waters, "The Constructive Trust in Evolution: Substantive and Remedial" in Equity and Contemporary Legal Developments (Goldstein ed., 1992) 457 at p.499.

115 ibid., p.490, n.77 and pp.499-505. See also Waters, "Trusts in the Setting of Business, Commerce and Bankruptcy" (1983) 21 Alta L Rev 395 at p.434.

116 n.114 above, at p.502.

117 Waters, n.114 above, at p.503. See also Waters, n.17 above, at pp.1216-1217.

118 McCormack, Proprietary Claims and Insolvency (1997), p.1; Oditah, "Assets and the Treatment of Claims in Insolvency" (1992) 108 LQR 459 at p.463 (noting the principle "explains remarkably little"). 
irrational to revise our concepts presently in the hope that they adequately accommodate that which we cannot foresee with any real precision. ${ }^{119}$

Second, legal forms that sit at either end of the finely shaded rules-discretion continuum are less workable in practice than in theory. ${ }^{120}$ While a highly individualised approach theoretically optimises the chance of reaching the most appropriate outcome, the reality is somewhat different. Doctrines that seek high degrees of individualised justice increase the risk of arbitrariness and mistake, lack certainty and predictability, and require the inefficient and time-consuming application of background policies. ${ }^{121}$

Certainty, predictability and efficiency are of particular significance in the context of in rem relief due to the potential for detriment to third parties. The more uncertain the position of third parties who deal with the disputed property, the greater the transaction costs of property dealings and the more difficult it is for individuals to take ex ante measures to protect their interests and rationally determine the risks involved in their dealings. Moreover, it is a primary concern of insolvency law to minimise the cost of determining priorities: the greater those costs the less remains of the already insufficient assets to meet the claims of creditors. Efficiency rather than finely tuned justice between each affected individual therefore assumes greater significance. The pure remedial approach is antithetical to these concerns. An elaborate, time-consuming and finely tuned balancing of the merits of individuals' claims increases the role, and hence costs, of the liquidator or trustee in bankruptcy. ${ }^{122}$ Moreover, uncertainty and unpredictability may encourage litigiousness in the desperate creditor: "scarcity begets innovation in the hungry creditor's quest to get a little more than the next fellow". ${ }^{123}$ The clearer the stated priorities the less hope there is for the desperate creditor to argue that his case is relevantly different from others in the queue, hence the less incentive to resort to litigation.

119 Birks forcefully reminded us of this, warning "against change which outstrips the intellect, and loses touch with the demand for stability and consistency": Birks, "Equity in the Modern Law: An Exercise in Taxonomy" (1996) 26 UWALR 1 at p.4.

120 See, e.g. Sunstein, n.28 above; Kaplow, "Rules Versus Standards: An Economic Analysis" (1992) 42 Duke LJ 557; Schauer, Playing by the Rules: A Philosophical Examination of Rule-Based Decision-Making in Law and in Life (1991), Ch.7; Schneider, n.28 above.

121 Waters appears to inconsistently suggest that his discretionary model does not lie in tension with these requirements: see Waters, n.114 above, at p.504. More recently, he has emphasised the rule-building nature of the discretion and suggested a need for the principled resolution of disputes: Waters, "The Nature of the Remedial Constructive Trust" in Frontiers of Liability (Birks ed., 1994), Vol.2, 165 at pp.184-185.

122 The approach also raises the possibility of conflict between separate court orders in favour of different claimants, each creating conflicting rights against the insolvent and other specified third parties.

123 Re Omegas Group Inc, n.49 above, at 1445. 


\section{The Institutional-Remedial Hybrid: Muschinski v Dodds and its Progeny.}

\section{(a) Muschinski v Dodds and subsequent interpretations}

Similarly stimulated by a desire to avoid prejudice to third party interests, the Australian courts have developed an approach that appears to blend inconsistently both institutional and remedial characteristics of the constructive trust. Institutional elements are evidenced by the characterisation of the trust as arising at the date of the operative facts and pre-existing judicial declaration. Remedial characteristics take the form of flexibility within the operation of the constructive trust, permitting the courts to tailor the consequences to meet with the demands of the case. The conceptualisation follows the influential judgment of Deane $\mathrm{J}$ in Muschinski v Dodds. ${ }^{124}$ Drawing on Scott, ${ }^{125}$ Deane J noted:

". . . notwithstanding that the constructive trust is remedial in both origin and nature, there does not need to have been a curial declaration or order before equity will recognise the prior existence of a constructive trust . . . Where an equity court would retrospectively impose a constructive trust by way of equitable remedy, its availability as such a remedy provides the basis for, and governs the content of, its imposition inter partes independently of any formal order declaring or enforcing it."126

However, later in his judgment his Honour further noted that "the constructive trust may be moulded and adjusted to give effect to the interplay of equitable principles in the circumstances of the particular case" and an order "can properly be so framed that the consequences of its imposition are operative only from the date of judgment or formal court order or from some other specified date." 127 In this particular instance, his Honour held "[1]est the legitimate claims of third parties be adversely affected, the constructive trust should be imposed only from the date of publication of reasons for judgment". ${ }^{128}$ On this reasoning, the constructive trust comes into existence automatically upon the facts, prior to curial declaration, but the court retains the power to vary the date from which the trust's consequences are operative. ${ }^{129}$

Two interpretations of the case have followed. The broad interpretation suggests there is maximal flexibility: a constructive trust may operate from the moment of the unconscionable conduct, from the date of judgment or from any intermediate or later date, as the justice of the case demands. Deane $\mathrm{J}$ appears to have supported such an expansive power when he commented that the constructive trust may operate "from the date of judgment or formal

(1985) 160 CLR 583.

125 Scott, The Law of Trusts (1967, $3^{\text {rd }}$ ed.), Vol 5, s.462.2.

126 n.124 above, at 615.

127 ibid., at 623 .

128 ibid.

129 The approach has been congratulated by many: see, e.g. Oakley, n.73 above, at pp.437-438 and 455 . 
court order or from some other specified date". ${ }^{130}$ A narrow interpretation permits a more restrictive choice: the constructive trust arises prior to curial declaration, but the court has the power to determine whether its consequences take effect from the moment of the conduct giving rise to its imposition or, alternatively, from the date of judgment. This interpretation more accurately reflects the actual outcomes of the cases, ${ }^{131}$ although more recently any flexibility as to the operative date of the constructive trust has been doubted, at least in relation to common intention constructive trusts. ${ }^{132}$

\section{(b) The merits of Muschinski and its progeny}

While both narrow and broad interpretations of Muschinski display a legitimate concern about the problematic effects of proprietary relief on third parties, they also raise a number of problems. To the extent that the broad interpretation represents a plea for individualised justice, it is susceptible to the same criticisms as are levelled against the pure remedial approach and contrary to the rejection by Deane $\mathrm{J}$ elsewhere in his judgment of abstract notions of justice and fairness when determining the appropriate relief. ${ }^{133}$ Both narrow and broad approaches also risk failing to avoid unwarranted and unintended priorities due to the court's necessary dependence on accurate information about the defendant's solvency.

With its emphasis on moulding, the approach has also created confusion and uncertainty because the extent to which the court can legitimately mould and manipulate the operation of the constructive trust remains unclear. Some lower courts have established a constructive trust by recourse to existing equitable doctrine but then, rather than consider timing of imposition, have proceeded to award a quite different form of relief. ${ }^{134}$ Other courts have further suggested that the constructive trust may be stripped of all of its consequences and no relief granted at all. ${ }^{135}$ This is needless circumlocution.

130 See the quote accompanying n.127 above (emphasis added). See generally Wright, The Remedial Constructive Trust (1998), pp.263-270; Wright, "The Statutory Trust, The Remedial Constructive Trust and Remedial Flexibility" (1999) 14 JCL 221.

131 Compare Re Sabri (1996) 21 Fam LR 213, Kidner v Secretary, Department of Social Security (1993) 31 ALD 63 and Re Jonton Pty Ltd [1992] 2 Qd R 105 (interest operative from time cause of action accrued) with Re Osborne (1989) 91 ALR 135 (common intention constructive trust not operative prior to husband's insolvency).

132 Parsons V McBain (2001) 192 ALR 772 (interest under constructive trust effective from the date the cause of action accrues, but, as a matter of priorities rather than timing of operation, may be deferred to later claims where the parties' conduct warrants it).

133 n.124 above, at 615.

134 For discussion and critical evaluation of these cases, see O'Connor, "Happy Partners or Strange Bedfellows: The Blending of Remedial and Institutional Features in the Evolving Constructive Trust" (1996) 20 MULR 735 at pp.745751; Austin, "The Melting Down of the Remedial Trust" (1988) 11 UNSWLJ 66.

135 Australian National Industries v Greater Pacific Investments Pty Ltd (in liquidation) (No3) (1992) 7 ACSR 176 at 190 per Cole J. The view is reminiscent of the Restatement, which conceptualises the constructive trust as arising automatically but being unenforceable where the legal remedy is adequate: see $n .9$ above, s.160, comments e \& f. 
Where a constructive trust "arises" but an alternative remedy is granted there is, in fact, no constructive trust. The facts simply create the grounds for the imposition of a different remedy. Talk of the constructive trust can drop out of the picture. Constructive trust terminology serves to designate a series of legal consequences attaching to particular facts. ${ }^{136}$ If such consequences do not follow, there is no constructive trust. ${ }^{137}$ Talk of the constructive trust can similarly drop out of the picture where its operation is apparently "suspended" and no remedy granted at all. Indeed, in such circumstances it is meaningless to talk of the claimant as having a cause of action: without a remedy there is no right.

\section{(c) The interim equity model}

In an attempt to avoid injustice to intervening third party interests, while avoiding the inconsistencies of Muschinksi, some have argued that the constructive trust claimant neither has, nor is deemed to have, an equitable interest in the disputed property prior to the court order. ${ }^{138}$ Rather, the potential constructive beneficiary's interest is simply an "equity" which is transformed into an equitable interest upon curial declaration. ${ }^{139}$ The constructive trust claimant will therefore not take priority over any equitable interest created in the interim, between the date of the facts giving rise to the constructive trust claim and the date of curial declaration, such as interests of purchasers under specifically enforceable contracts and equitable mortgages. ${ }^{140}$ The potential beneficiary will, however, continue to enjoy priority over the constructive trustee's unsecured creditors by virtue of the general principle that a trustee in bankruptcy is bound by all of the equities affecting the bankrupt. ${ }^{141}$

There is, however, little support for the interim equity model in the authorities of any Commonwealth jurisdiction. Indeed, there exists contrary authority on the very issue in question. Thus, in Re Jonton Pty Ltd ${ }^{142}$ it was held that, although a common intention constructive trust was not declared judicially until 1991, the claimant's equitable proprietary interest existed from the time of the events giving rise to the claim. Since these occurred in

136 Dobbs, n.20 above, at p.398.

137 It is for this reason that Dobbs brands the analogous US orthodoxy "a fling with esoteric metaphysics": n.20 above, s.4(3)(2), n.1. See also Palmer, Law of Restitution (1978) s.1.4.

138 Most notably, Glover, "Bankruptcy and Constructive Trusts" (1991) 19 Aus Bus L Rev 98.

139 ibid., at pp.109-110.

140 Latec Investments Ltd v Hotel Terrigal Pty Ltd (1965) 113 CLR 265; Re Papaloizou (1980) [1999] BPIR 106 (Browne-Wilkinson J); Phillips v Phillips (1861) 4 De GF \& J 208.

141 Ex parte Holthausen (1874) LR 9 Ch App 722 at 726 per James LJ; Re Clark, ex parte Beardmore [1894] 2 QB 393 at 410 per Davey LJ. Similar principles apply upon corporate insolvency: see Anderson, "The Treatment of Trust Assets in English Insolvency Law" in Commercial Aspects of Trusts and Fiduciary Obligations (McKendrick ed., 1992) 167 at p.172.

142 [1992] 1 Qd R 105. 
the 1970 s the claimant took priority over the equitable interest of a mortgagee whose claim dated from the 1980s. ${ }^{143}$

The approach also fails to develop a form of specific relief that does not bind unsecured creditors. It simply addresses the problem of priority between competing equitable interests, reversing the existing rules of priority. Is this really necessary? While there may be justification to subordinate a constructive trust claim to a later equitable interest, this will not always be so. Exceptions will be therefore required just as there is presently a perceived need for exceptions to the "first in time" rule that presumptively favours the constructive trust claimant. A sensitive and effective solution to this problem may be already within our grasp, without widespread conceptual change. We might keep the existing approach, classifying the unclaimed constructive trust interest as an equitable interest, but where required conclude that the merits are unequal so that the equity first in time (the constructive trust claimant) does not prevail. ${ }^{144}$ Dealing with the matter by reference to more flexible priority rules is also likely to avoid the significant confusion that would follow the classification of a claim as an "equity", given the protean and indeterminate nature of the term. ${ }^{145}$

Undesirable and unforeseen practical consequences may also follow such wholesale change of the constructive trust claimant's interest prior to curial declaration, thus conflicting with the principle of minimal conceptual disturbance. For example, the blanket classification of the potential constructive trust claimant's interest as an "equity" may disturb the application of various statutory regimes in which the temporal requirement of a proprietary interest assumes significance. An example of some currency from the United States concerns the temporal requirement of an interest in property under the Racketeering Influenced Corrupt Organization Act (RICO). ${ }^{146}$ This legislation allows the government to seize assets that belong to the wrongdoer at the time of any illegal action falling within the Act. Thus, in those Circuits adopting the "automatic vesting" or "automatic retrospectivity" conceptualisations the constructive trust claimant is not

143 See also Re Sabri (1996) 21 Fam LR 213. Priorities between constructive trust claimant and competing interests are determined in English law in the same manner. Thus, in Re Morgan (1881) LR 18 Ch D 93 an executor of a deceased's estate renewed a lease in his own name and afterwards deposited the lease as security for a loan which he applied for his own purpose. The claim of the estate took priority over that of the depositee because the estate's equitable interest (under a constructive trust which arose by operation of the rule in Keech v Sandford (1726) Sel Cas Ch 61) was first in time.

144 Heid $\mathrm{v}$ Reliance Finance Corporation Pty (1983) 154 CLR 326 at 341-342 per Mason \& Deane JJ. Such flexibility may not exist in English law, although see MacMillan v Bishopgate Investment Management (No3) [1995] 3 All ER 747 at 768 per Millett J (order of priority may be reversed in "special circumstances"); Rice v Rice (1854) 2 Drew 73 per Kindersley VC (explaining the maxim qui prior est tempore, potior est jure operates as a tie-breaker, to be applied only where there is no other ground for choosing between the competing claims).

145 As to which, see Everton, “"Equitable Interests' and 'Equities' - In Search of a Pattern" [1976] Conv 209; Smith, Property Law (4th ed., 2003), pp.29-31; Skapinker, "Equitable Interests, Mere Equities, 'Personal' Equities and 'Personal Equities' - Distinctions With a Difference” (1994) 68 ALJ 593.

14618 USC 1963. 
subordinated to the government's RICO claim: the disputed property either belonged or is deemed to have belonged to the claimant, not the defendant, at the time the illegal act was committed. ${ }^{147}$ However, changing the conceptualisation changes the priorities. Where the courts have accepted the view that the constructive trust, properly conceived, is a remedy that can arise and operate only when declared, it follows that the defendant and not the claimant owned the disputed asset at the time the illegal act was committed. The government is therefore able to seize the asset as an asset of the wrongdoer at the appropriate time, creating a result that is arguably contrary to the legislative intent of Congress. ${ }^{148}$ Similar problems may occur closer to home, if all constructive trusts were to operate from the time of declaration only. ${ }^{149}$ One might also consider the problems that would have arisen when a potential constructive trust claimant sought to assert their interest against a third party by virtue of the Land Registration Act 1925, section $70(1)(\mathrm{g}) .{ }^{150}$ If the claimant's interest was classified as a mere equity the temporal requirement that the appropriate proprietary interest be in existence at the time of the actual occupation would not be satisfied. ${ }^{151}$

\section{Conclusion: Towards A New Analytical Framework}

This review suggests that the various conceptual shapes into which the constructive trust has been moulded fail to work for us as effectively as they might. The automatic vesting approach persists in English law for reasons of ideology, not utility. It avoids consideration of crucially important normative concerns and potentially perpetuates unjust and largely unintended judicially created priorities. Its operation and interplay with related doctrine lacks logic and often depends on reasoning that is, at best, grossly artificial. Oakley's automatically retrospective conceptualisation avoids some of these difficulties but similarly portrays priority over third parties as an inevitable and natural consequence of the constructive trust, reflecting the traditional reluctance of English judges and jurists to engage openly in critical normative issues affecting priorities.

Other approaches, developed against the background of more progressive judicial cultures, have been motivated by the desire to address openly the very issue that the institutional constructive trust suppresses: the justice of the constructive trust claim against innocent third parties. Developments in Canada are perhaps the most promising. There, it is recognised that in some

147 See US v Schwimmer 968 F 2d 1570 at 1582 (2d Cir 1992) and US v Lavin $942 \mathrm{~F}$ 2d 177 at 187 (3d Cir 1991).

148 US v BCCI Holdings $46 \mathrm{~F} 3 \mathrm{~d} 1185$ (DC Cir 1995).

149 A subsisting equitable interest may be of importance in England for taking otherwise relevant property outside the operation of similar confiscation regimes, because such regimes will respect third party rights in property subsisting at the time of confiscation order: see, e.g. HM Customs \& Excise Commissioners and Long v A [2002] EWHC 611 at [171], affirmed [2002] EWCA Civ 1309 at [23][24], [50]-[54], discussing the Drug Trafficking Act 1994, s.31(4). See now Proceeds of Crime Act 2002, s.69(3).

150 See now Land Registration Act 2002, Sch.3, para.2.

151 See now Land Registration Act 2002, s.116, by which a mere equity is capable of binding successors in title. Note, however, that the language of "mere equity" may not be taken literally: Smith, n.145 above, at p.31. 
cases the constructive trust binds third parties legitimately; in others it does justice between claimant and defendant only to the extent that innocent third parties are not prejudiced. The problem is that the latter cases continue to be dealt with via the language of constructive trust. This makes "constructive trust" do too much and obscures the individuality of what is in substance a different remedy with different intended consequences. It also fails to avoid the risk of unintended and unwarranted priorities because it places such a heavy reliance on the availability of information about the defendant's solvency. There is reason to believe that the quality of such information will be often poor, leaving a court to second guess the appropriateness of the imposition of a constructive trust. The hybrid approaches developed in Australia post-Muschinski are problematic for similar reasons.

These pitfalls are avoided, and justice and clarity enhanced, by the recognition of two conceptually distinct remedies: the constructive trust and the personal order to transfer specific property. The constructive trust is more appropriately conceptualised as a judicially imposed interest in property operating retrospectively from the time the claimant's cause of action accrued. It should be given a reduced sphere of operation and imposed only where there is reason to grant the claimant the significant benefits that follow from the recognition or creation of equitable property rights, particularly priority over creditors and supervening interests. By this approach, judicial responsibility for the outcome is emphasised. Moreover, the gross artifice and logical deficiencies of the automatic vesting approach are avoided.

The purely personal order to transfer specific property would exist alongside the constructive trust. ${ }^{152}$ It would operate in those cases previously dealt with by the constructive trust in which specific relief is desirable but priority is not. It would, for example, provide a more satisfactory way forward in disgorgement cases. In these cases recovery is premised on the desire to deter wrongful conduct rather than correct a material loss. ${ }^{153}$ What is

152 Professor Goode alludes to the need for specific relief that does not prejudice creditors. However, he limits the operation of the device to "deemed agency gains", would continue to recognise an automatic vesting constructive trust, and is ambivalent as to whether such a remedial order should confer on the claimant a prospective proprietary interest or a purely personal right to the transfer of specific property: see Goode, "Property and Unjust Enrichment" in Essays on the Law of Restitution (Burrows ed., 1991) 215; Goode, "The Recovery of a Director's Improper Gains: Proprietary Remedies for Infringement of NonProprietary Rights" in Commercial Aspects of Trusts and Fiduciary Obligations (McKendrick ed., 1992) 137 at pp.146-148.

153 The most obvious cases are those in which a fiduciary receives a secret profit, such as a bribe or profitable opportunity, from a third party in breach of his duty of loyalty: see, e.g. Attorney General for Hong Kong v Reid [1994] 1 AC 324; Boardman v Phipps [1967] 2 AC 46. This is not to say, however, that all bribe and opportunity cases fall out with the category of correction of material loss. It is to say simply that some do. I do not therefore include as instances of disgorgement those bribe and opportunity cases in which the principal can demonstrate a loss corresponding to the defendant's gain by direct or interceptive subtraction: see, e.g. Daraydan Holdings Ltd v Solland [2004] EWHC 622 (Ch) (bribe subtracted from claimant) and Cook v Deeks [1916] 1 AC 554 (interceptive subtraction of corporate opportunity). 
therefore important is not that the claimant receives the benefit but that the defendant does not. The claimant is simply an "accidental beneficiary of a rule of public policy". ${ }^{154}$ Consequently, it is difficult to find justification for elevating the claimant to the status of secured creditor. ${ }^{155}$ A purely personal order to transfer specific property would enhance the law's ability to effect full disgorgement where the gain is non-fungible without risking the creation of unintended and unwarranted priorities. Others argue for a similar result but by reference to the distorting language of discretion and the remedial constructive trust. They argue that a court should possess discretion to impose a constructive trust, but that discretion should not be exercised positively where the defendant is insolvent or supervening third party interests are present. ${ }^{156}$ This does not sound like a proprietary remedy, nor does it sound like discretion. It is a call for the imposition or recognition of an in personam obligation to disgorge a gain in specie. The notion of a purely personal order to transfer specific property more faithfully represents what is being sought. It also affords a way of avoiding unintended priorities and the expense and difficulty of an inquiry into the defendant's solvency.

This, of course, leaves much unsaid about any reclassification. Which cases should remain within the scope of the constructive trust? Which are more appropriately dealt with by the personal order to transfer specific property? And are there other areas to which the personal order, free from priority problems, could be extended? These questions may prove difficult and generate controversy, but they raise issues that are there already and which will not go away. The benefit of the framework for analysis proposed here is that it clarifies the choices to be made and illuminates what is at stake in making them.

154 McCarey v Associated Newspapers Ltd (No.2) [1965] 2 QB 86 at 107 per Diplock LJ.

155 See, e.g. Sherwin, n.18 above, at pp.329-340; Paciocco, "The Remedial Constructive Trust: A Principled Basis for Priority Over Creditors" (1989) 68 Can Bar Rev 315 at pp.349-350. Indeed, given that the claimant is receiving a windfall, it is difficult to find justification for granting a disgorgement claim even equal status to other unsecured claims: see, e.g. Jaffey, "Disgorgement and Confiscation" [1996] RLR 92 at p.97.

156 See, e.g. Cope, "Ownership, Obligation, Bribes and the Constructive Trust" in Equity Issues and Trends (Cope ed., 1995) 91. 